\title{
Validity of the Apatite/Merrillite Relationship in Evaluating the Water Content in the Martian Mantle: Implications from Shergottite Northwest Africa (NWA) 2975
}

\author{
Ewa Słaby ${ }^{1, *}$, Hans-Jürgen Förster ${ }^{2}$, Richard Wirth ${ }^{2}$, Alicja Wudarska ${ }^{1,2}$, tukasz Birski ${ }^{1}$ and \\ Izabela Moszumańska ${ }^{1}$ \\ 1 Institute of Geological Sciences, Polish Academy of Sciences, Research Centre in Warsaw, Twarda 51/55, \\ 00-818 Warsaw, Poland; ndgiera@cyf-kr.edu.pl (A.W.); 1.birski@twarda.pan.pl (Ł.B.); \\ i.moszumanska@twarda.pan.pl (I.M.) \\ 2 Helmholtz-Zentrum Potsdam Deutsches GeoForschungsZentrum GFZ, Telegrafenberg, 14473 Potsdam, \\ Germany; hans-juergen.foerster@gfz-potsdam.de (H.-J.F.); richard.wirth@gfz-potsdam.de (R.W.) \\ * Correspondence: e.slaby@twarda.pan.pl
}

Received: 17 July 2017; Accepted: 26 September 2017; Published: 4 October 2017

\begin{abstract}
Phosphates from the Martian shergottite NWA 2975 were used to obtain insights into the source and subsequence differentiation of the melt/melts. The crystallization of two generations of fluorapatite ( $\mathrm{F}>\mathrm{Cl} \sim \mathrm{OH}$ and F-rich), chlorapatite and ferromerrillite-merrillite were reconstructed from TEM (Transmission Electron Microscopy) and geochemical analyses. The research results indicated that the recognized volatiles budget of the two generations of fluorapatite was related to their magmatic origin. The apatite crystals crystallized from an evolved magma during its final differentiation and degassing stage. In turn, chlorapatite replaced ferromerrillite-merrillite and was not related to, mantle-derived shergottite magma. The relationship between merrillite and apatite indicates that apatite is most probably a product of merrillite reacting with fluids. REE (rare earth elements) pattern of $\mathrm{Cl}$-apatite might point to an origin associated with exogenous fluids mixed with fluids exsolved from evolved magma. The study shows that, among the three types of apatite, only the fluorapatite $(\mathrm{F}>\mathrm{Cl} \sim \mathrm{OH})$ is a reliable source for assessing the degree of Martian mantle hydration. The occurrence of apatite with merrillite requires detailed recognition of their relationship. Consequently, the automatic use of apatite to assess the water content of the magma source can lead to false assumptions if the origin of the apatite is not precisely determined.
\end{abstract}

Keywords: fluorapatite; chlorapatite; ferromerrillite; volatiles; shergottite; TEM; EPMA; LA-ICP-MS

\section{Introduction}

Phosphates that occur in extra-terrestrial mafic rocks may provide information regarding water (volatiles) content in the environment leading to their formation and transformation (e.g., [1-17]). The magma source for Martian basalts is the Martian mantle; thus, the basaltic phosphates provide information on the Martian mantle composition as well as its evolution in the course of melting progression [11,18-21]. Volatile-bearing apatite $\left(\mathrm{Ca}_{10}\left(\mathrm{PO}_{4}\right)_{6}(\mathrm{Cl}, \mathrm{F}, \mathrm{OH})_{2}\right)$, volatile-free merrillite $\left(\mathrm{Ca}_{18} \mathrm{Na}_{2} \mathrm{Mg}_{2}\left(\mathrm{PO}_{4}\right)_{14}\right)$ and the high-pressure phase tuite $\left(\gamma-\mathrm{Ca}_{3}\left(\mathrm{PO}_{4}\right)_{2}\right)$ are frequently observed in extra-terrestrial bodies $([1,3,5,6,12,22-25]$ and references therein). These minerals are thought to be of different origins due to their joint or separate occurrence and their chemical and structural transformation processes. The transformation from volatile-bearing to volatile-absent phases has been observed in meteorites and has been reproduced experimentally [24]. Shock events may lead to the 
structural/compositional transformation of phosphates [26] and to the formation of high-pressure polymorphs [22-25].

Chlorapatite and merrillite are the most frequently occurring Ca-phosphates in Martian and lunar basaltic rocks $([2,9,12,14,27-34]$ and references therein). The occurrence of chlorapatite and merrillite is related to magma differentiation [2,9-13,27-33,35-38] or post-magmatic transformation processes, which frequently occur due to interactions with fluids (e.g., $[10,14,16,26,39,40])$. Phosphate saturation is commonly attributed to late-magmatic evolution. For example, Mikouchi et al. [35] identified merrillite as a late-stage magmatic differentiation phase in the Queen Alexandria Range 94201 shergottite (shergottite is a Martian crustal rock of basaltic composition that mainly consists of olivine, pyroxene and plagioclase). In addition, a similar origin for apatite and merrillite was suggested by He et al. [30], Shearer et al. [38] and others. However, in the experiments conducted by Herd et al. [36] regarding shergottite crystallization, merrillite was observed as the only phosphate and was nucleated as liquidus phase.

Many models consider REE (rare earth elements) and volatile activity in the melt or post-magmatic fluids as controlling factors for Ca-phosphate nucleation and crystallization/recrystallization. Using geochemical models based on the REE concentration of lunar phosphates, Jolliff et al. [27] suggested several scenarios for their formation. For example, apatite and merrillite may crystallize simultaneously or sequentially or may equilibrate with local melt pockets. Shearer et al. [10] explained that the presence of coexisting merrillite and chlorapatite in the GRA 06129 (06128) achondrite resulted from the reaction of merrillite with fluids that lead to chlorapatite crystallization. According to McCubbin et al. [12], substitution of a whitlockite component in a merrillite coexisting with OH-rich apatite in shergottite may be indicative of formation in equilibrium with hydrothermal or aqueous fluids. In the Chassignyshergottite, McCubbin and Nekvasil [8] observed two generations of apatite that differed in their halogen concentrations, and they related this transition to magmatic and post-magmatic processes. Howarth et al. [26] reported F-rich and OH-F-rich apatites accompanied by interstitial Cl-rich apatite from the lherzolitic shergottite NWA 7755. They demonstrated a devolatization of apatite crystals by shock melting, which caused significant $\mathrm{Cl}$ enrichment in the adjacent regions. They considered the F-rich apatite crystals to be primarily magmatic. The $\mathrm{OH}-\mathrm{F}-\mathrm{rich}$ apatite crystallized from magma exsolving $\mathrm{Cl}$-rich fluids, which in turn lead to formation of an interstitial Cl-rich apatite. Three generations of apatite in NWA 7755 coexist with merrillite. Similar relationships were found in other shergottites [20,39]. Deciphering the magma source composition and magma differentiation in terms of the volatile content requires detailed study of the phosphate paragenesis [26].

The present study shows three generations of apatite coexisting with merrillite in the evolved shergottite NWA 2975 [30,41,42]. Despite some similarities with previously studied shergottites, the formation/transformation path of the NWA 2975 phosphates is different. Similar to previous studies, a question arises on the reliability of the acquired data for the reconstruction of the composition of the source of the melt from which the mafic rock crystallized.

\section{Reasoning for the Selection of NWA 2975 and the Current State of NWA 2975 Research}

The shocked, highly evolved shergottite NWA 2975 [29,30,41-43] was chosen for the study. The aim was to determine the phosphate compositions and structures to gain insights into the processes contributing to their formation and transformation. Previous studies on this meteorite have reported the joint occurrence of two phosphate species, merrillite and chlorapatite [29,30,41,42], with zoned pyroxene, maskelynite (a glass phase with a plagioclase composition), other accessory minerals and glass veins/pockets. Within the maskelynite, He et al. [41] also found fine, symplectitic intergrowths composed of fayalite, silica, Fe-Ti oxides and phosphate.

Wittke et al. [29] reported and related the occurrence of merrillite in NWA 2975 to melt pockets, which are widespread in ulvöspinel. Quenched melt inclusions are surrounded by ferropigeonite crystals, merrillite and pyrrhotite rimming glass. However, no geochemical data from the phosphates 
were provided. He et al. [30] documented the REE pattern of merrillite in shergottite but not in apatite. Phosphates are considered a crystallization product of residual melts that are substantially enriched in Fe and REEs. He et al. [41] provided new data on the Raman spectra and trace element concentrations of merrillite. The investigated crystals contain quite high concentrations of volatiles, including $\mathrm{Cl}$. The Raman spectrum resembles that of unshocked crystals; thus, the spectra might imply merrillite crystallization after shock melting. Additionally, stishovite, seifertite and dense $\mathrm{SiO}_{2}$ glass were attributed to crystallization from shock-derived melt. In turn, the appearance of zoned pyroxene was related to two distinct Martian mantle reservoirs yielding LREE-depleted and LREE-enriched melts.

The study of Słaby et al. [42] confirmed the presence of merrillite and chlorapatite, as previously reported by Wittke et al. [29]. In addition fluorapatite was identified. Transmission Electron Microscopy (TEM) was used to determine the magmatic characteristics of the fluorapatite crystal. Thus, the crystals were used to evaluate the water content in the Martian mantle, the source of the shergottite magma. Volatile concentrations were estimated using an electron microprobe, polarized synchrotron Fourier Transform Infrared-(FTIR) and Raman-spectroscopy. The focused ion beam technique (FIB) was used for IR-sample preparation. It was concluded that the water content in the shergottite magma source was comparable with that of the terrestrial Mid-Ocean Ridge Basalts (MORB) environment.

\section{Analytical Approach}

\subsection{Sample Description}

The NWA 2975 sample material consists of a rock slab measuring $2 \mathrm{~cm} \times 2 \mathrm{~cm} \times 0.3 \mathrm{~mm}$. Two thin sections (30 $\mu \mathrm{m}$ thickness) were prepared from this sample and were mounted on glass slices with epoxy.

\subsection{EPMA (Electron Probe Microanalysis)}

The thin sections were coated with a $20 \mathrm{~nm}$ thick carbon film and analyzed for a suite of major and minor elements with the use of a JEOL thermal field-emission instrument (JXA-8500F, HYPERPROBE, (JEOL Ltd., Akishima, Japan) at the Helmholtz Center Potsdam German Research Centre for Geosciences GFZ, Germany. Quantitative spot analyses of apatite were conducted following the measurement protocol of Słaby et al. [42] and with an acceleration voltage of $15 \mathrm{kV}$, a beam current of $5 \mathrm{nA}$, and a spot size of $8 \mu \mathrm{m}$. Natural and synthetic standards used for the measurement calibration were as follows (the elements and peak counting times are listed in parentheses): fluorite (F, $10 \mathrm{~s})$, albite (Na, $10 \mathrm{~s})$, diopside (Mg, $20 \mathrm{~s})$, orthoclase (Al, $20 \mathrm{~s}, \mathrm{Si}, 10 \mathrm{~s})$, apatite (P, $20 \mathrm{~s}, \mathrm{Ca}, 10 \mathrm{~s}), \mathrm{ZnS}$ (S, $20 \mathrm{~s})$, tugtupite $(\mathrm{Cl}, 20 \mathrm{~s})$, rhodonite $(\mathrm{Mn}, 20 \mathrm{~s}), \mathrm{Fe}_{2} \mathrm{O}_{3}(\mathrm{Fe}, 20 \mathrm{~s})$ and celestine $(\mathrm{Sr}, 20 \mathrm{~s})$. Merrillite crystals were analyzed with an acceleration voltage of $20 \mathrm{kV}$, a beam current of $10 \mathrm{nA}$, and a spot size of $10 \mu \mathrm{m}$. The peak counting times using the indicated calibration materials were as follows: fluorite (F, $10 \mathrm{~s})$, $\mathrm{MgO}(\mathrm{Mg}, 20 \mathrm{~s})$, apatite (P, $10 \mathrm{~s}, \mathrm{Ca}, 10 \mathrm{~s}), \mathrm{ZnS}$ (S, $20 \mathrm{~s})$, tugtupite (Cl, $20 \mathrm{~s}, \mathrm{Na}, 10 \mathrm{~s}, \mathrm{Al}, 20 \mathrm{~s}, \mathrm{Si}, 20 \mathrm{~s})$, rhodonite (Mn, $20 \mathrm{~s}), \mathrm{Fe}_{2} \mathrm{O}_{3}(\mathrm{Fe}, 20 \mathrm{~s})$ and celestine (Sr, $\left.10 \mathrm{~s}\right), \mathrm{CePO}_{4}(\mathrm{Ce}, 50 \mathrm{~s}), \mathrm{LaPO}_{4}(\mathrm{La}, 50 \mathrm{~s}), \mathrm{YbPO}_{4}$ $(\mathrm{Yb}, 50 \mathrm{~s}), \mathrm{NdPO}_{4}(\mathrm{Nd}, 50 \mathrm{~s}), \mathrm{SmPO}_{4}(\mathrm{Sm}, 50 \mathrm{~s})$ and $\mathrm{YPO}_{4}(\mathrm{Y}, 50 \mathrm{~s})$. The background counting times were set to half of the respective peak counting times. The PRZ correction algorithm for oxides after Armstrong was used for data processing.

\subsection{EDS (Energy Dispersive Spectrometry) Mapping}

Thin section elemental maps (Figure 1) were made to identify phase relationships in the thin sections. The following parameters were used: $20 \mathrm{kV}$ accelerating voltage, $100 \mathrm{nA}$ beam current, $10 \mu \mathrm{m}$ steps; $2100 \mathrm{cps} / \mathrm{s}, 2700$ sweep counts and $17 \mathrm{~h}$ analysis time. 


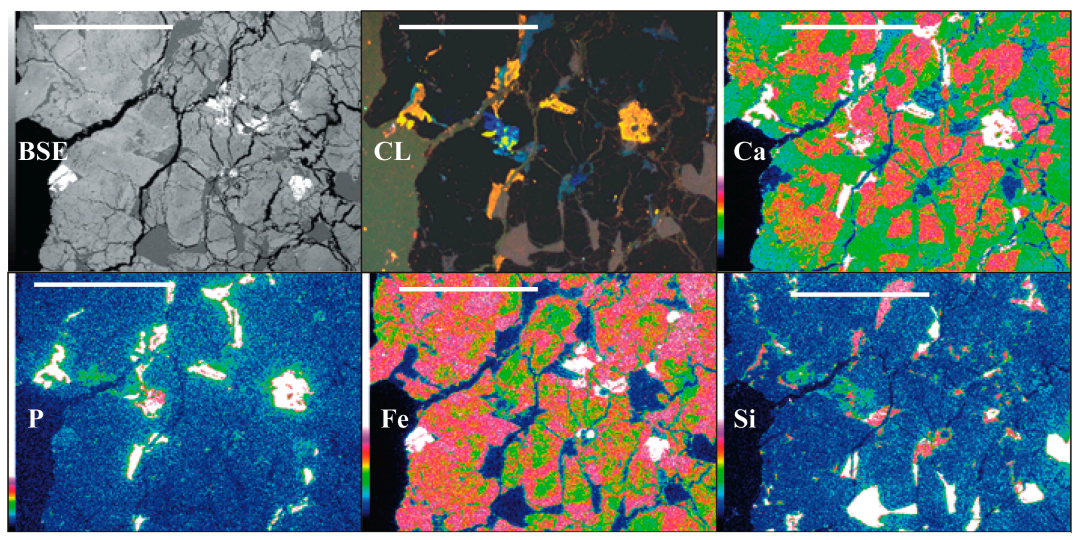

Figure 1. The thin section: backscattered electrons (BSE) and cathodoluminescence (CL) images and the elemental maps. The rock is mainly composed of zoned pyroxenes (cores enriched in Ca, rims enriched in Fe; no luminescence), maskelynite and glass (Si distribution; blue, dull-violet luminescence) and Ca-phosphates (dull-orange luminescence). Scale bar-1 $\mathrm{mm}$.

Backscattered electrons (BSE) imaging and element mapping (Figure 2) were conducted using a Zeiss Ultra Plus scanning electron microscope coupled with a Thermo Fischer EDS Detector with a $20 \mathrm{kV}$ acceleration voltage and a $1 \mathrm{nA}$ current. EDS maps of $1024 \times 768$ resolution were collected simultaneously for up to 14 elements for approximately $6 \mathrm{~min}$. BSE images were combined with $\mathrm{Cl}$ and P maps using NSS 2.2 software (Thermo Fischer) to distinguish associated crystals of apatite and merrillite.
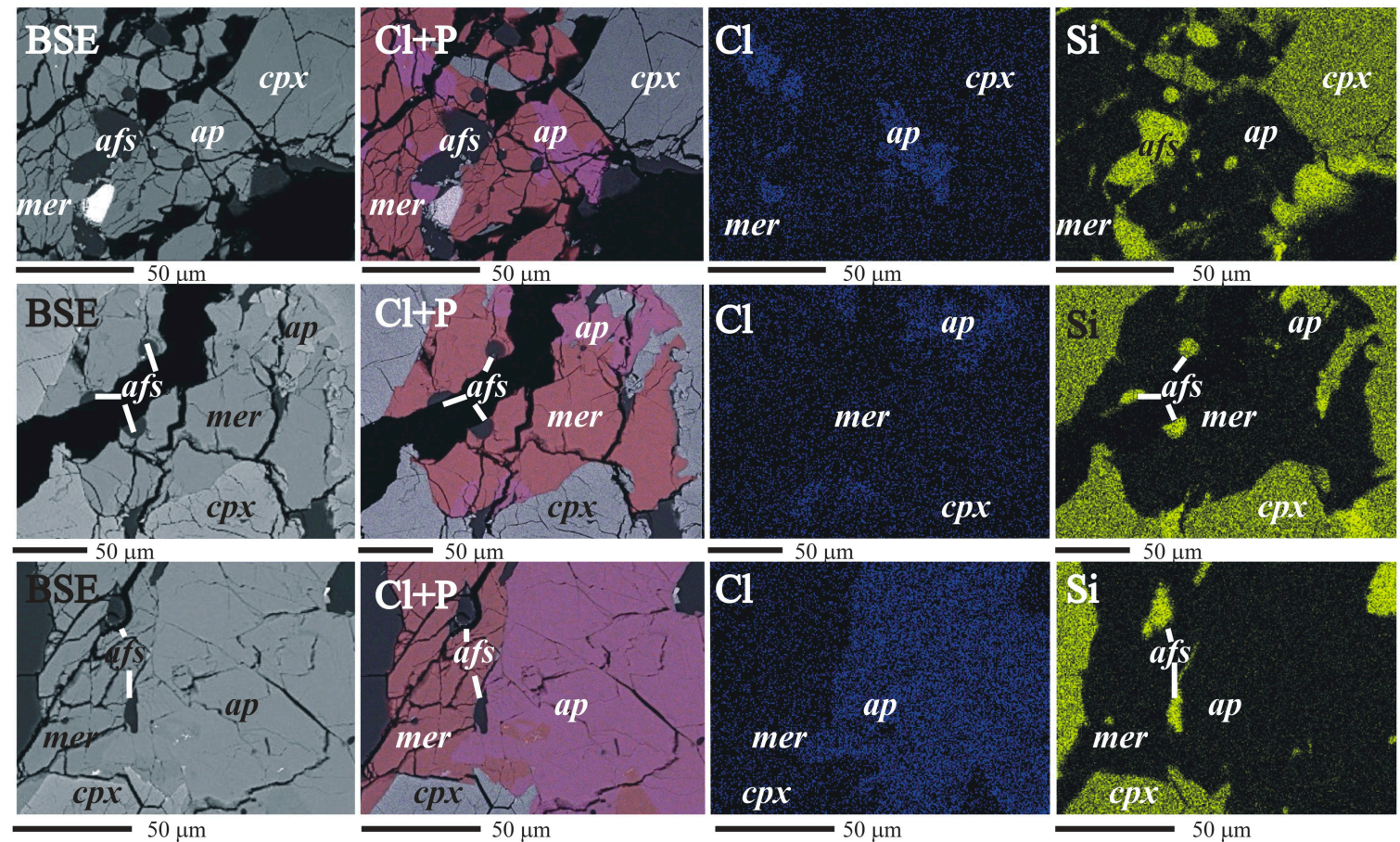

Figure 2. Apatite/merrillite relationship elemental maps (cpx, clinopyroxene; mer, merrillite; ap, apatite; afs, alkali feldspar).

\subsection{LA-ICP-MS (Laser Ablation Inductively Coupled Plasma Mass Spectrometry)}

A set of analyses was conducted on the phosphates and pyroxenes at the Institute of Geological Sciences at the Polish Academy of Sciences, Kraków Research Centre. For these analyses, a $193 \mathrm{~nm}$ 
excimer laser-ablation system (RESOlution M50 by Resonetics) was coupled with a quadrupole ICP-MS (XSeriesII by Thermo). Details regarding the performance of the RESOlution M50 are provided by Müller et al. [44]. Ablation occurred in pure He (at a flow rate of $0.9 \mathrm{~L} / \mathrm{min}$ ), to which Ar nebulizer gas (at a flow rate of $0.5-0.55 \mathrm{~L} / \mathrm{min}$ ) was mixed downstream of the two-volume LA cell. After passing through a signal-smoothing device, the analyte was delivered to the ICP source. A small addition of nitrogen $(0.006-0.008 \mathrm{~L} / \mathrm{min})$ was used to enhance the sensitivity of the ICP-MS. The oxide level $\left({ }^{248} \mathrm{ThO} /{ }^{232} \mathrm{Th}\right)$ was kept below $0.5 \%$. Analyses were performed using a spot size of $30 \mu \mathrm{m}$, a fluence of 3-4 J/ $\mathrm{cm}^{2}$ and a repetition rate of $10 \mathrm{~Hz}$. Each $40 \mathrm{~s}$ ablation time was preceded by a $20 \mathrm{~s}$ blank and followed by a $20 \mathrm{~s}$ washout. Sample runs were bracketed by measurements of the NIST 612 glass [45]. The calcium concentration was used as an internal standard.

\subsection{TEM (Transmission Electron Microscope) Analysis}

TEM analysis was conducted to determine the phosphate structure and study any possible shock-induced effects. Sample preparation was accomplished by using focused ion beam (FIB) milling. TEM-ready foils of approximately $20 \mu \mathrm{m} \times 10 \mu \mathrm{m} \times 0.15 \mu \mathrm{m}$ were directly sputtered from the crystal grains in the epoxy grain mount. The TEM foils were placed on a perforated carbon film on a copper grid. No carbon coating was applied to prevent charging under the electron beam. Details regarding the TEM sample preparation are provided elsewhere [46,47]. TEM was performed using a FEI Tecnai F20 X-Twin TEM (Thermo Fisher, Hillsboro, Oregon, USA) with a Schottky field emitter as an electron source. The TEM was equipped with a Gatan Tridiem ${ }^{\text {TM }}$ imaging filter (GIF) (Gatan Inc., Pleasanton, CA, USA), a Fishione high-angle annular dark field detector (HAADF) (Fishione Instruments, Inc., 9003 Corporate Cir, Export, PA 15632, USA) and an EDAX X-ray analyzer (EDAX AMETEK, Weiterstadt, Germany) with an ultrathin window. The D-spacing $\left(\mathrm{d}_{\mathrm{hkl}}\right)$ was calculated from the high-resolution lattice fringe images that were transformed into diffraction patterns by applying fast Fourier transformation (FFT). The observed $d_{\text {hkl }}$ values were compared with the values that were calculated from the crystal structures obtained from the literature. To unambiguously identify a phase, the observed angles between the diffraction vectors must match the angles that are calculated from the crystal structure within $1^{\circ}$.

\subsection{CL (Cathodoluminescence)}

Cathodoluminescence (CL) microscopy was used to document the growth of internal textures within the phosphates. The CL measurements were performed on carbon-coated, polished thin sections using a Nikon ECLIPSE 80i (Nikon Corporation, Tokyo, Japan) with a cold cathode (CITL Cathodoluminescence Mk5-2; Cambridge Image Technology Ltd (CITL) Cambridge, UK) that was operated at an accelerating voltage of $16.6 \mathrm{kV}$ and a current density of ca. $428 \mu \mathrm{A} / \mathrm{mm}^{2}$. Luminescence images were captured on-line with a Nikon DS-Ri1 digital video camera (Nikon Corporation, Tokyo, Japan).

\section{Results}

Clinopyroxene is the predominant mineral and shows mottled-patchy zoning that results from $\mathrm{Ca}$ enrichment in the core (augite) and from Fe in the rim (pigeonite) (Figure 1; compare Ca and Fe maps). The margins of clinopyroxene are more homogeneous, whereas the core shows traces of melting/dissolution (Figure 3a). The second most frequent mineral associated with glass pockets and veins is maskelynite (Figure $3 b$ ). The phosphate distribution is frequently related to cracks, but they also appear without any clear relationship to cracks (Figure 1; CL). The crystals located along the fractures and holes adjust their formation to the crack shape. The crystals are accompanied by inclusions of alkali feldspar or laths of alkali feldspar attached to them (Figure 1; $\mathrm{Si}, \mathrm{Ca}$, and P). Phosphates associated with major phases, such as pyroxene and maskelynite show more automorphic habits. In addition to accessory phosphates, Ti-enriched ulvöspinel, ilmenite, and pyrrhotite have been found. 

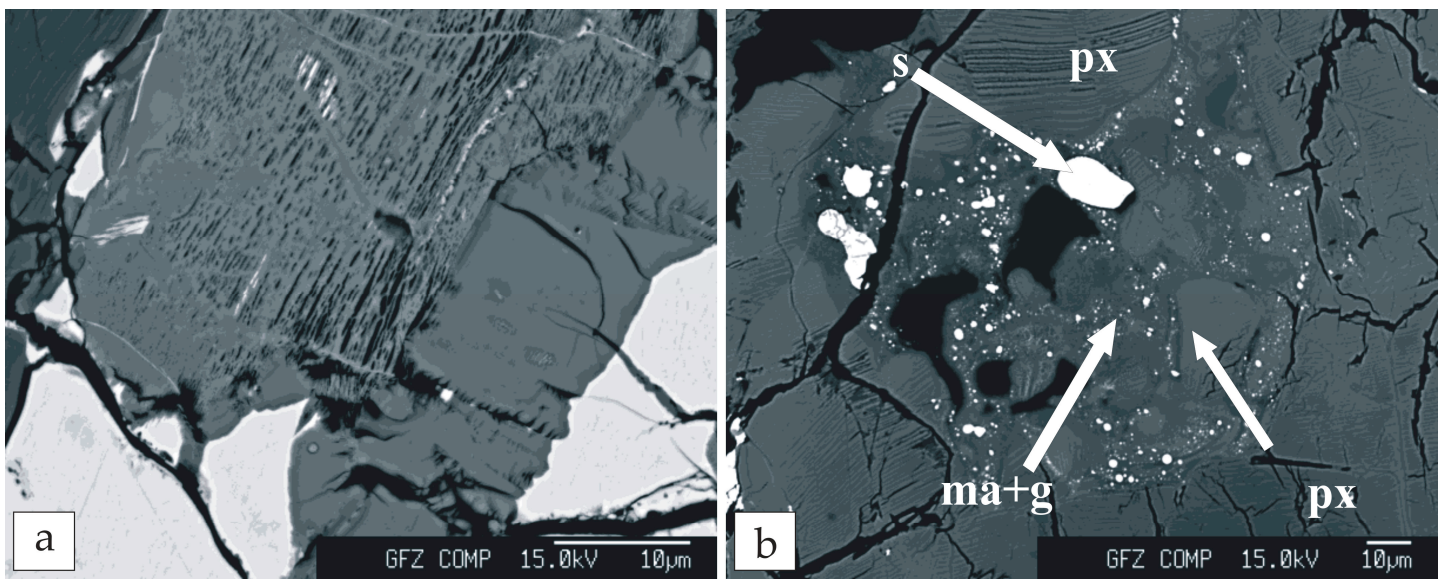

Figure 3. Phase relationships: (a) Pyroxene with melting/dissolution textures; and (b) multi-phase pockets. Abbreviations: ma+g, maskelynite and glass; px, pyroxene; s, sulfides.

\subsection{Data}

Phosphates show weak, orange-brownish luminescence related to manganese. Occasionally, the revealed growth pattern is slightly patchy (Figure $1 \mathrm{CL}$ ), with a duller core and a brighter, narrow rim. The inhomogeneity is not visible under the polarizing microscope. The weak red-violet maskelynite luminescence and the bright blue luminescence of alkali feldspar are related to shock events [48].

\subsection{Phosphate Composition}

The elemental maps and chemical data were used to identify the spatial relations between the different phosphates. Fluorapatite, merrillite and interstitial chlorapatite (crystallized in cracks) were recognized. Merrillite occurs as single crystals as well as intergrowths with chlorapatite (Figure 2). The contact between merrillite and chlorapatite is poorly visible in BSE images (Figure 2), but it is well defined on $\mathrm{Cl}$ elemental maps (Figure 2). Small inclusions along the contact between the two phases are alkali feldspar (Figure 2). Merrillite is noticeable within chlorapatite, indicating the replacement of one phase by another.

The chemical composition of both apatite populations and merrillite were determined with EPMA and LA-ICP-MS. The results of EPMA spot analyses and the mean compositions of these phosphates, together with the crystallochemical formulas, are provided as Supplementary Materials (Tables S1 and S2).

The mean chemical formula of the NWA 2975 apatite occurring as individual grains not spatially associated with merrillite (obtained from 51 time-regressed analyses and calculated on the basis of 13 total anions) is $\left(\mathrm{Ca}_{4.86} \mathrm{Fe}_{0.07} \mathrm{Na}_{0.02} \mathrm{Mg}_{0.01} \mathrm{Mn}_{0.01}\right)_{4.97}\left(\mathrm{P}_{2.92} \mathrm{Si}_{0.05} \mathrm{~S}_{0.01}\right)_{2.98} \mathrm{O}_{12}\left(\mathrm{~F}_{0.45} \mathrm{Cl}_{0.28} \mathrm{OH}_{0.27}\right)_{1.00}$. These data identify the apatite as fluorapatite showing a narrow range in compositional variation. Chlorine occupies $22-37 \%$ of the halogen site, which exceeds the amount reported for most terrestrial mafic complexes [3]. The $\mathrm{OH}$ content calculated on the basis of measured $\mathrm{F}$ and $\mathrm{Cl}$ data and based on the assumption that the $(\mathrm{F}, \mathrm{Cl}, \mathrm{OH}, \mathrm{O})$ site is completely filled varies $15-34 \%$, which is equivalent to $0.27-0.61$ wt $\% \mathrm{H}_{2} \mathrm{O}$.

The composition of the apatite associated with merrillite is different. This apatite usually classifies as chlorapatite and spans a comparatively larger range in composition (cf. Table S1). Sixteen time-regressed analyses yield a mean formula $\left(\mathrm{Ca}_{4.82} \mathrm{Fe}_{0.06} \mathrm{Na}_{0.04} \mathrm{Mn}_{0.01}\right)_{4.93}\left(\mathrm{P}_{2.92} \mathrm{Si}_{0.03} \mathrm{~S}_{0.01}\right)$ ${ }_{2.96} \mathrm{O}_{12}\left(\mathrm{~F}_{0.18} \mathrm{Cl}_{0.60} \mathrm{OH}_{0.22}\right){ }_{1.00}$. Chlorine accounts $24-83 \%$ of the halogen site. The $\mathrm{OH}$ content is inferred to vary within $10-34 \%$, corresponding to $0.17-0.61 \mathrm{wt} \% \mathrm{H}_{2} \mathrm{O}$.

Figure 4 highlights differences in composition between the two populations of apatite that occur with merrillite and without. On all bi-variate elemental diagrams, there is greater data scatter of the 
chlorapatite associated with merrillite. $\mathrm{Cl} / \mathrm{OH}$ varies in a narrow range in fluorapatite, whereas $\mathrm{F} / \mathrm{Cl}$ in chlorapatite varies widely. The $\mathrm{F} / \mathrm{Cl}$ ratio versus $\mathrm{F} / \mathrm{OH}$ ratio exhibits a linear relationship. The $\mathrm{Fe}$ content varies within a similar range in both apatites and is better correlated with the $\mathrm{OH}$ content than with the $\mathrm{Cl}$ content.

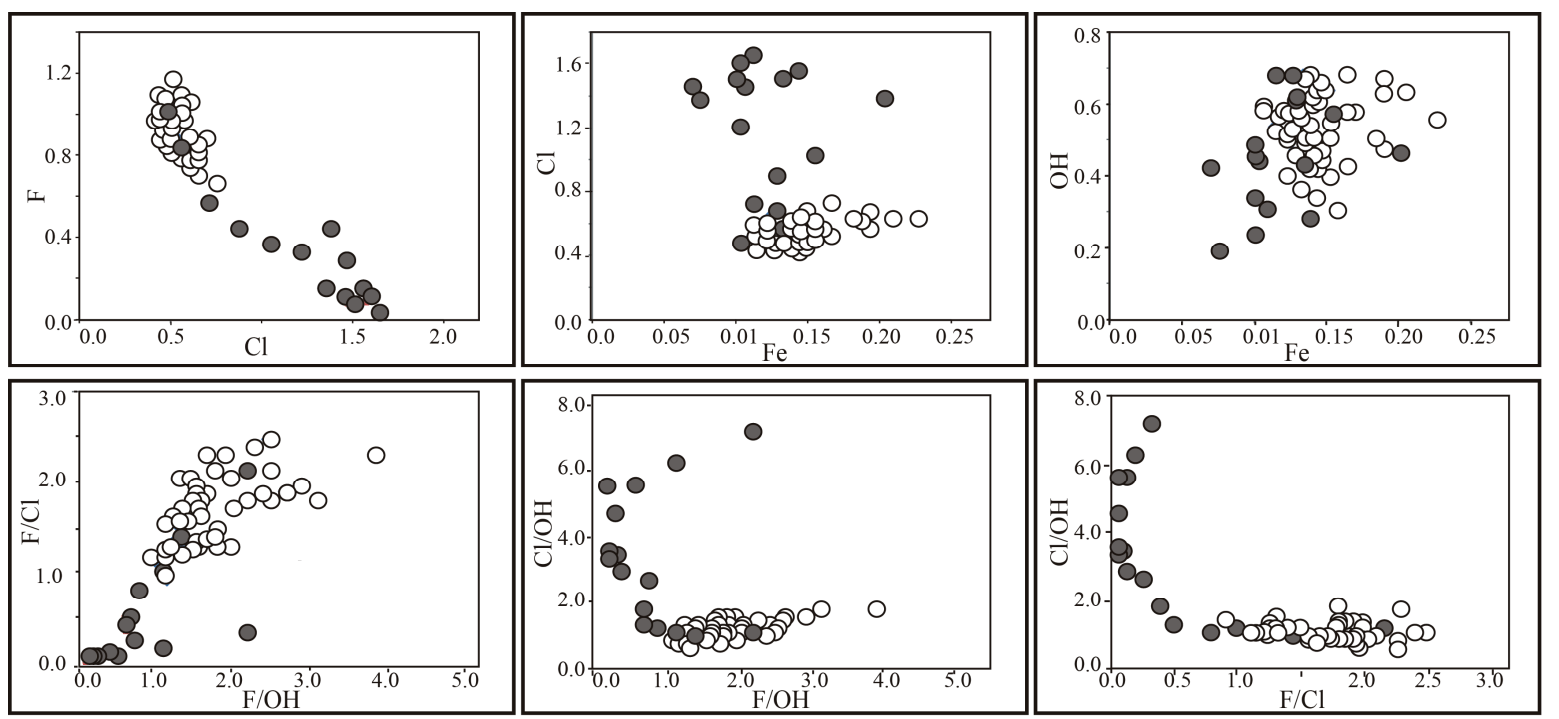

Figure 4. Apatite composition (elements ratio per formula unit; open symbols, fluorapatite; filled symbols, chlorapatite).

The REE concentrations in the apatite were near the detection limit of the EPMA; thus, the concentrations were determined using LA-ICP-MS. The CI-chondrite-normalized REE pattern of fluorapatite is depleted in LREEs, with $\mathrm{Nd}$ depletion and a pronounced negative Eu anomaly (Figure 5). In addition, the MREEs were slightly enriched. The apatite pattern tends to demonstrate the features of the so called "tetrad effect", which consists of four convex patterns in the subdivisions of La-Nd, $\mathrm{Pm}-\mathrm{Gd}, \mathrm{Gd}-\mathrm{Ho}$ and Er-Lu [49]. Although this effect is small, it is clearly defined. The apatite is also enriched in $\mathrm{Ba}, \mathrm{Sr}$, and $\mathrm{Rb}$ and depleted in $\mathrm{Y}$ (Supplementary Materials, Table S3).

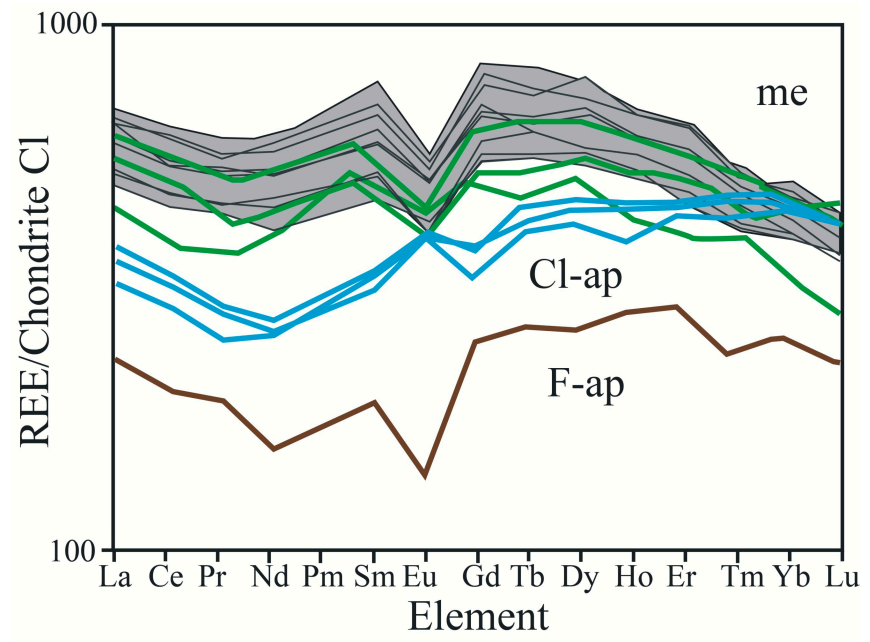

Figure 5. Chondrite-normalized REE patterns for the F-apatite (brown), $\mathrm{Cl}$-apatite (blue) and merrillite (grey area). For comparison, merrillite REE patterns from other shergottite after [41] (green).

The few $\mathrm{Cl}$-apatite patterns collected close to merrillite exhibit flat LREE patterns, positive Eu anomalies and increasing enrichment in MREEs and HREEs (Figure 5). These patterns are located 
between apatite and enriched merrillite patterns. The Eu concentration for the middle group is similar to the first one; however, strong LREE depletion causes the normalized REE pattern to exhibit a positive $\mathrm{Eu}$ anomaly. Ignoring the different shape of the Eu anomaly and the generally much greater REE enrichment, the pattern resembles that of apatite.

Most of the extra-terrestrial phosphates from the whitlockite group are compositionally close to merrillite, i.e., they are dry with variable amounts of $\mathrm{Na}, \mathrm{Fe}$ and $\mathrm{Mg}$ [4-6]. Trace abundances of halogens in extra-terrestrial merrillite have also been reported [6,12,50].

Microprobe analyses of merrillite grains from NWA 2975, recalculated on the basis of 28 oxygen atoms, define this phosphate as intermediate member of the merrillite [Cag $\mathrm{NaMg}$ $\left(\mathrm{PO}_{4}\right)_{7}$ ]-ferromerrilite $\left[\mathrm{Ca}{ }_{9} \mathrm{NaFe}\left(\mathrm{PO}_{4}\right)_{7}\right]$ solid-solution series (Table S2, Supplementary Materials). In contrast to what was established for apatite, merrillite-ferromerrillite associated and not associated with apatite is compositionally indistinguishable within the limits of analytical error. The mean composition of independent grains of merrillite-ferromerrillite obtained from 48 spots and normalized to 28 oxygen atoms is $\mathrm{Ca}_{9.24} \mathrm{Mg}_{0.56} \mathrm{Fe}_{0.52} \mathrm{Na}_{0.51} \mathrm{Mn}_{0.02}\left(\mathrm{P}_{6.93} \mathrm{Si}_{0.02} \mathrm{Al}_{0.01}\right)_{6.96}$. The mean composition of chlorapatite-associated merrillite-ferromerrillite grains (17 spots) amounts to Ca9.16 $\mathrm{Mg}_{0.55} \mathrm{Fe}_{0.52} \mathrm{Na}_{0.50} \mathrm{Mn}_{0.02} \mathrm{Ce}_{0.01} \mathrm{Y}_{0.01}\left(\mathrm{P}_{6.96} \mathrm{Si}_{0.02}\right)_{6.96}$. All grains contain detectable concentrations of REE. Some grains contain $\mathrm{Cl}$ amounts at the limit of detection (<50 ppm). Trace abundances of halogens in extra-terrestrial merrillites have been reported $[6,12,50]$.

Similarly to apatite analyses, most of the trace element concentrations in merrillite were measured using LA-ICP-MS (Supplementary Materials, Table S3). Merrillite is rich in Y and poor in Ba, Sr and $\mathrm{Rb}$. The CI-chondrite-normalized REE pattern of the merrillite showed a conspicuously negative Eu anomaly, a kink at Nd and elevated MREE concentrations. The LREEs were depleted relative to the MREEs (Figure 5).

\subsection{TEM}

Four foils were cut from the meteorite for the TEM study. Calculated diffraction patterns (FFT) from the high-resolution images were used to determine the structural parameters $\left(\mathrm{d}_{\mathrm{hkl}}\right)$ (Figures 6-8) of both of the phosphates. The phosphates were identified and indexed as apatite (Figures 6 and 7) and merrillite (Figure 8), and the unit cell parameters of the apatite (first generation) were derived from the diffraction patterns (FFT) $\left(a_{0}=b_{0}=8.19 \AA\right)$. The calculated angle between the (11-20) and (01-10) planes was $30^{\circ}$, which corresponded to the observed angle. The second indexed crystal (first generation), which contains a vein of fine platy apatite, had the following unit cell parameters: $\mathrm{a}_{0}=\mathrm{b}_{0}=8.3 \AA$ (Figure 6a,c). In addition, the calculated (11-22)/(01-10) angle was 59.18 with an observed angle of $59.4^{\circ}$, and the calculated (11-22)/(10-12) angle was $19.57^{\circ}$ with an observed angle of $19.6^{\circ}$ [42]. Planar deformation lamellae were visible in the fluorapatite (typical for high shock pressure) on both the BF and HREM [42]. Some areas with deformation microstructures merge into undisturbed areas (Figure 6b). The diffraction pattern of fluorapatite corresponds to almost a single crystal pattern. However, this image shows streaking in the $\{01-10\}$ direction, which indicates that the diffracting volume is composed of many small platelets of the same crystal that are oriented normal to the streaks [42]. In addition, inclusions of pure silica occur within the shocked domains. 


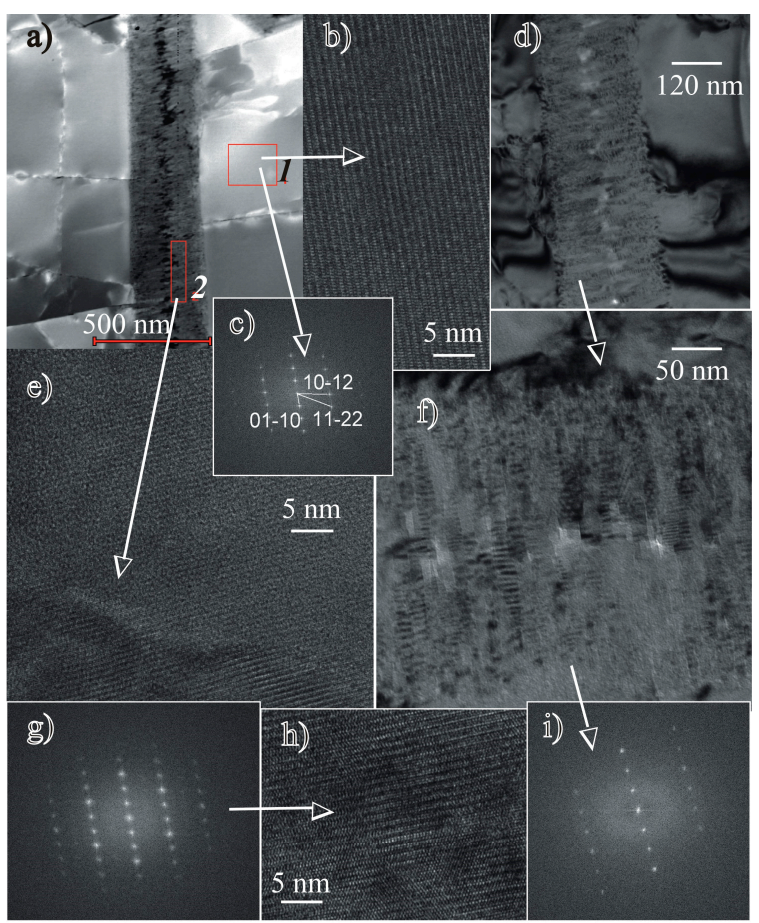

Figure 6. Transmission Electron Microscope (TEM) photomicrographs of the two generations of apatite: (a) High-angle annular dark-field (HAADF) image of the first-generation fluorapatite with some chlorine (1) and a vein of fine-grained second-generation chlorine-free apatite in a crack (2); $(\mathbf{b}-\mathbf{c})$ lattice fringe image of early apatite and its indexed diffraction pattern (enlarged "a" image ); and $(\mathbf{d}-\mathbf{i})$ late apatite (second generation). The lath-shaped crystals nucleated on the walls of the cracks and grew towards the centre. The lattice fringe image of the late crystals and their diffraction pattern are indicative of apatite. The indices are the same as those shown in Figure 7c. Thus, the crystallographic orientation was identical between the first- and second-generation apatites.
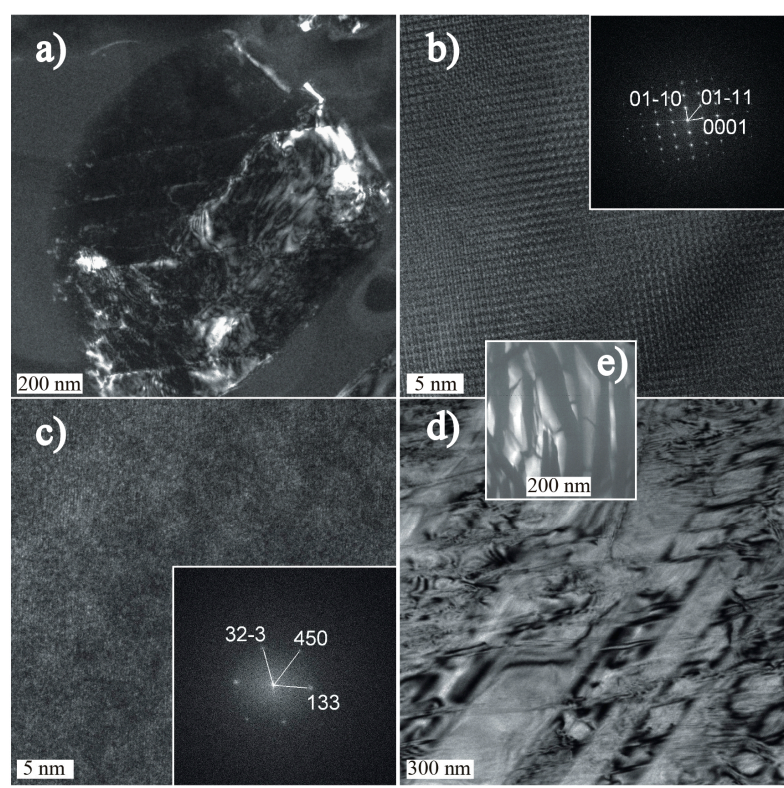

Figure 7. Transmission Electron Microscope (TEM) photomicrographs of mineral associations in the shergottite cracks: (a) Cl-apatite; (b) lattice fringe image and the corresponding diffraction pattern (FFT) of Cl-apatite; (c) Zr-Ti oxide inclusions-lattice fringe image with indexed diffraction pattern; (d) pyroxene-rim part of the crystal; and (e) partly recrystallized silica-rich glass pocket. 


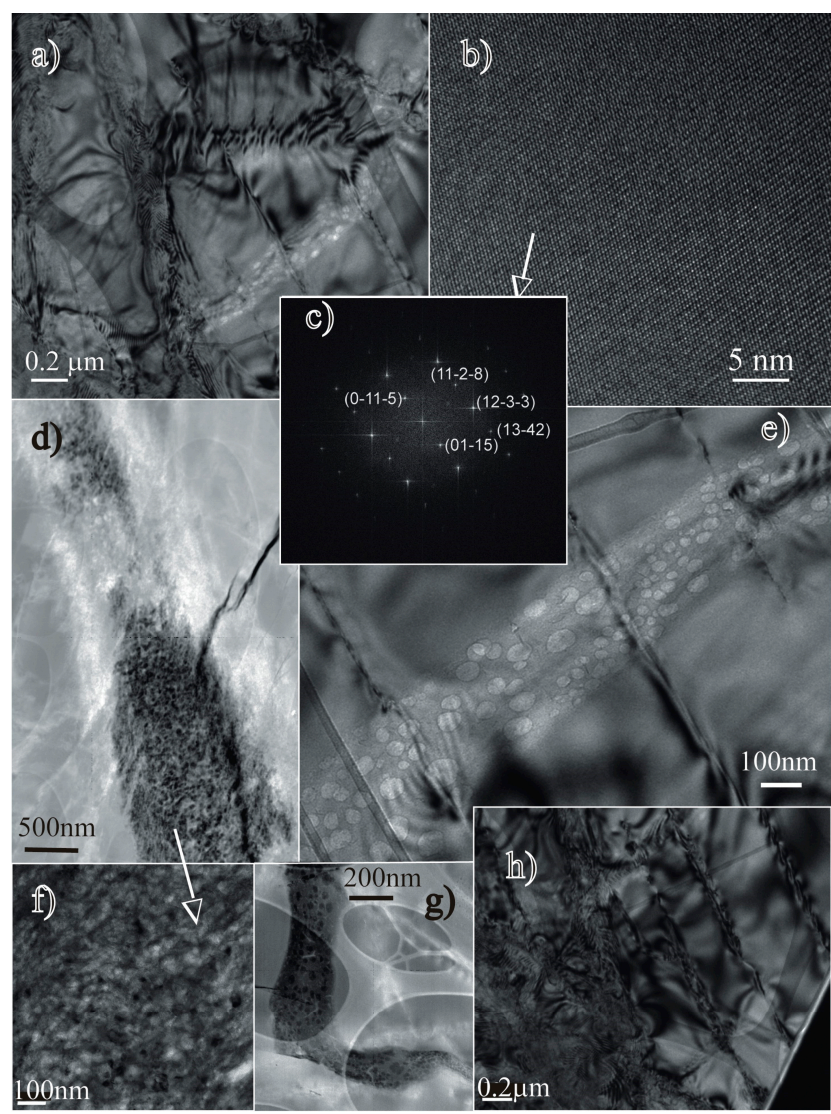

Figure 8. Transmission Electron Microscope (TEM) photomicrographs of the i (a) Bright field (BF) image of the merrillite with a trail of "bubbles" in the lower part of the image (for comparison, refer to the magnified portion with some planar deformation across the trail - image " $\left.\mathrm{e}^{\prime \prime}\right)$; $(\mathbf{b}-\mathbf{c})$ lattice fringe image and the corresponding diffraction pattern (FFT) (note the perfect regular structure of the crystal domain without any sign of distortion); (d,e,f) recrystallized melt pockets $(\mathrm{d}, \mathrm{f})$ and a trail of "bubbles" (e-magnification of image "a"), which shows no offset by the planar features, which suggests a later formation event; (g) L-shaped porous domain that shows traces of volatiles (big elipsoids-copper grid holder); and (h) disturbed crystal domain (the right side of the picture demonstrates the planar deformations).

In some locations, the cracks in the apatite are filled with fine-grained, lath-shaped, apatite crystals (Figure 6a-f) that we interpret as a second generation. These crystals pile up on the crack walls towards the crack center (Figure 6a,d,f). Their growth morphology and mutual orientation show that they nucleated on the crack walls and grew in parallel-oriented stacks. The nucleation of the second-generation of apatite growth on the surface of the first-generation apatite is documented by the identical crystallographic orientation of the first- and second-generation apatites. The diffraction patterns in Figure 6c (first-generation apatite), the images in Figure 6g,i are identical. Planar defects are difficult to recognize in such small crystals. However, the structures of these areas are slightly distorted in places (Figure 6e,h). The crystals were indexed as apatite based on the d-spacing and the angles between the adjacent planes; however, their compositions differed from the host-apatite. The platy crystals are F-rich and do not contain $\mathrm{Cl}$. The EDS spectra showed a considerable decrease in the Fe content.

Interstitial chlorapatite (Figure 7a-b) is accompanied by inclusions of unidentified Ti-Fe-rich inclusions (Figure 7c). Silica-rich veins of glassy materials contain fragments of pyroxene (Figure 7e). The contact of the glass with these minerals does not show any evidence of in situ melting, and the 
glass is partly crystallized. Parallel-oriented plates with triangular habits and pure $\mathrm{SiO}_{2}$ compositions occur within the amorphous material (Figure 7e).

The merrillite (Figure 8a-h) unit cell parameters that were derived from the diffraction patterns (FFT) (Figure 8c) are $\mathrm{a}_{0}=\mathrm{b}_{0}=10.339 \AA$ with $\mathrm{c}_{0}=37.029 \AA$. A comparison between the observed $\mathrm{d}_{\mathrm{hkl}}$ data and the calculated d-spacings for the merrillite according to the literature [5] is presented in Table 1.

Table 1. Crystallographic data of merrillite.

\begin{tabular}{lll}
\hline $\mathbf{D}_{\text {hkl }}$ Observed (̊̊) & Indices & D-Spacing Calculated $^{\mathbf{1}}$ \\
\hline 8.13 & $(-1102)$ & 8.0784 \\
5.65 & $(01-15)$ & 5.1789 \\
5.18 & $(11-20)$ & 5.1810 \\
4.78 & $(-1-123)$ & 4.7787 \\
4.15 & $(-2025)$ & 3.8396 \\
3.89 & $(10-19)$ & 3.7464 \\
3.17 & $(12-3-3)$ & 3.2710 \\
2.63 & $(21-39)$ & 2.6193 \\
2.41 & $(13-42)$ & 2.4668 \\
\hline Angles Between Planes Observed & Angles Between Planes Calc. & FFT Nr. \\
\hline$(13-42) /(01-15)=44.0^{\circ}$ & $(13-42) /(01-15)=44.31^{\circ}$ & HREM06 \\
$(13-42) /(12-3-3)=23.4^{\circ}$ & $(13-42) /(12-3-3)=23.55^{\circ}$ & \\
$(-2025) /(-1-123)=28^{\circ}$ & $(-2025) /(-1-123)=27.94^{\circ}$ & HREM06a \\
$(-2025) /(-1102)=52.6^{\circ}$ & $(-2025) /(-1102)=52.38^{\circ}$ & \\
$(21-39) /(11-20)=40.0^{\circ}$ & $(21-39) /(11-20)=40.68^{\circ}$ & HREM06b \\
$(21-39) / 10-19)=28.3^{\circ}$ & $(21-39) / 10-19)=28.12^{\circ}$ & \\
\hline
\end{tabular}

${ }^{1}$ Merrillite, trigonal, $\mathrm{a}_{0}=\mathrm{b}_{0}=10.3620 \AA \mathrm{c}_{0}=37.106 \AA$ [5]

Similar to shocked apatite crystals, the bright field photomicrographs of merrillite revealed a set of irregularly spaced, planar defects in the crystals (Figure 8a,e,h), which are typical of high shock pressure. Small pockets of quenched melt/fluid were found within the merrillite crystals (Figure 8d,f,g). These pockets (Figure 8f) demonstrated very porous textures (Figure 8g), were silica-rich, and contained traces of volatiles (with $\mathrm{F}$ predominating over $\mathrm{Cl}$ ). Other textures that were found in the merrillite suggested the presence of gas-rich quenched fluid/liquid trails (Figure 8a,e). These quenched, very porous melt drops containing phosphate, silica and volatiles (with $\mathrm{F}$ predominating over $\mathrm{Cl}$ ) only occur in the merrillite.

\section{Discussion}

The present study provides data on ferromerrillite and three types of apatite. One of them, F-rich apatite, has significant amounts of substituted $\mathrm{Cl}$ and water. This type of apatite was previously considered rare among the studied Martian apatites, which were mostly recognized as chlorapatites with an average $\mathrm{Cl}-\mathrm{F}-\mathrm{OH}$ molar ratio of 5:3:2 [28]. However, McCubbin and Nekvasil [8] reported two generations of apatite, and one of them i.e., F-rich apatite, was considered a product of late magmatic differentiation. The second one, the $\mathrm{Cl}-\mathrm{F}-$ rich apatite, was attributed to crystallization from an exsolved $\mathrm{Cl}-\mathrm{H}_{2} \mathrm{O}$-rich fluid phase. Howarth et al. [26,39] reported primary, magmatic OH-F-rich apatite with some $\mathrm{Cl}$-rich domains, which were attributed to interactions with shock melts or with fluids. The TEM study [42] recognized fluorapatite $\left(\mathrm{F}_{0.50} \mathrm{Cl}_{0.28} \mathrm{OH}_{0.22}\right)$ crystals in NWA 2975 as a phase crystallizing from an evolved melt. Their growth textures suggest a magmatic origin (Figure 6). No post-magmatic alterations were observed. The phosphates were characterized by lamellae that were separated by planar features. The individual lamellae were composed of much smaller crystals that showed individual diffraction contrast. The individual crystals were free of dislocations but were separated from each other by dislocation arrays. The high-resolution lattice fringe images revealed mosaicisms of several variably distorted and undistorted sub-domains that resembled microstructures indicative of shock-induced deformation [42]. In Figure 9, these apatite crystals are concentrated along a fractionation trend, confirming the previous recognition as a magmatic phase. The fluorine variation in the crystals is small and may point to continuous, equilibrated growth from the magma. 

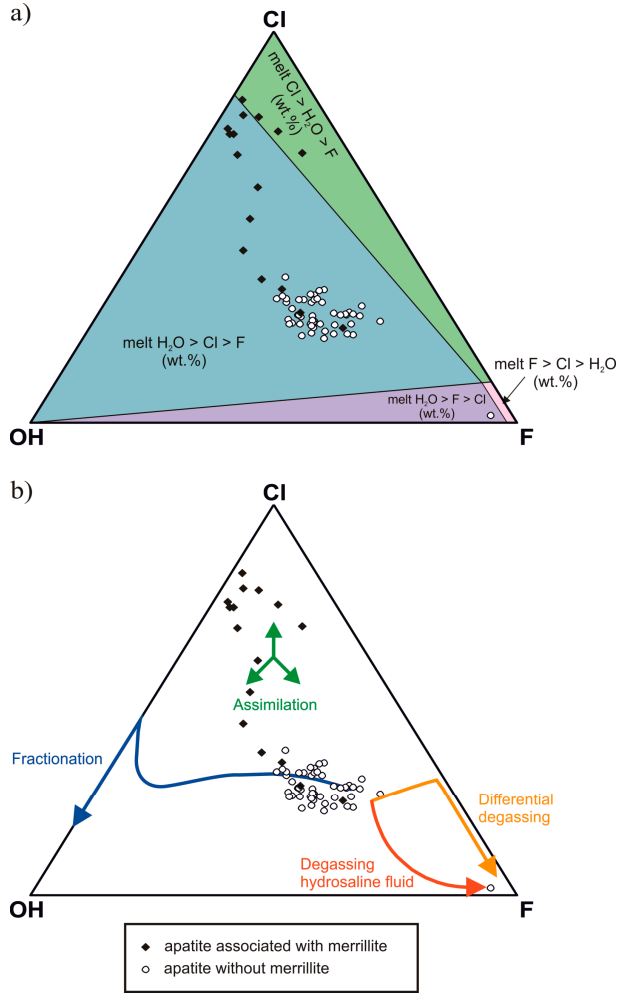

Figure 9. Ternary plots of apatite X-site occupancy (mol \%) for NWA 2975 (a) relative volatiles content in magma; (b) evolutionary trends (after Howarth et al. [39]).

TEM combined with EDS analysis provided further information. Whereas fluorapatite, the product of late fractional crystallization, contained $\mathrm{F}$ and $\mathrm{Cl}$, the second generation found in its cracks was pure F-apatite (Figure $6 \mathrm{~d}-\mathrm{i}$ ). This pattern indicates that $\mathrm{Cl}$ was lacking during the last crystallization stage.

Fluorine is strongly partitioned in the melt (e.g., [51-57]), whereas $\mathrm{Cl}$ shows strong affinity to exsolved fluids. McCubbin et al. [12,58] and Vander Kaaden et al. [59] define the order of preference as follows: $\mathrm{F}>\mathrm{Cl}>\mathrm{OH}$. Hence, $\mathrm{F}$ plays an important role in stabilizing magmatic apatite, and during degassing, apatite compositions evolve towards the F-rich member. In the NWA 2975 magma, the fluorine activity was high until the very end of crystallization and potentially promoted the crystallization of pure fluorapatite from the residual melt after degassing. Howarth et al. [39] pointed to two paths of degassing, which may influence apatite composition during late crystallization. The paths are $\mathrm{fO}_{2}$ (close to QFM) dependent [56,57], i.e., they differ for lower and higher QFM. The calculated $\mathrm{fO}_{2}$ for NWA 2975 [42] suggests exsolution at high pressure and $\mathrm{fO}_{2}$ conditions, in which $\mathrm{Cl}$ and $\mathrm{H}_{2} \mathrm{O}$ are preferentially partitioned into a fluid leaving $\mathrm{F}$ into the residual melt. Consequently, the composition of apatite that crystallized after degassing should approach the pure F-rich member.

The third apatite is $\mathrm{Cl}$-rich and occurs in association with merrillite. It was also found in cracks close to partly recrystallized glass pockets (Figure 7). The TEM observations of merrillite suggested magmatic crystallization and did not indicate any post-magmatic recrystallization (Figure 8). Merrillite does not seem to be related to another phosphate shock-transformation [17]. However, the TEM observations also revealed microstructures that were compatible with shock metamorphism. The effects of shock metamorphism are potentially associated with ejection from the Martian subsurface and were documented in all major phases. The observations revealed planar deformations or mosaicisms of several variably distorted and undistorted sub-domains, which indicated shock-induced deformation. It seems that merrillite and fluorapatite precipitated prior to the shock event. The shock event was not strong enough to transform the merrillite structure into the high-pressure polymorph, tuite. 
The structures of the phosphates can be identified as apatite and merrillite. Traces of both halogens were recognized in the recrystallized melt inclusions in the merrillite (Figure $8 \mathrm{~d}, \mathrm{f}, \mathrm{g}$ ).

The petrogenesis of NWA 2975 is related to two distinct mantle magma reservoirs: LREE-enriched and LREE-depleted [41]. Ancient mantle heterogeneity and progressive crystallization of ascending magmas derived from the mantle may produce zoned pyroxene. Ferdous et al. [60] showed that a shergottite with a similar composition could have resulted from crystallization in a closed system. Crustal contamination cannot be excluded, as isotope data on the rock sample are unavailable. However, crystallization of the highly evolved magmatic liquid of NWA 2975 [29,30,41] should result in merrillite with a Fe-rich composition. The lower Fe content may point to simultaneous Fe-rich pyroxene and merrillite crystallization and to an Fe-rich competition between them. Wittke et al. [29] found Fe-rich pigeonite and merrillite around cores of Si-Al-K-Na-rich glass. The occurrence of merrillite next to Fe-rich pigeonite may suggest their simultaneous crystallization. The GERM database includes $\mathrm{Kd}_{\mathrm{Fe}}$ values for low-Ca pyroxene, but none for merrillite. However, both minerals are REE carriers, and the appropriate partition coefficients are presented in GERM. In merrillite, REEs are compatible, while, in pyroxene, REEs are incompatible. The merrillite CI-chondrite-normalized REE patterns indicate crystallization from variably REE-enriched melts (Figure 5). Local enrichment potentially plays an important role in the formation of merrillite. We used the La and $\mathrm{Yb}$ concentrations in apatite and their average concentrations in merrillite and Fe-rich pyroxene to obtain information regarding the approximate composition of the shergottite melt. A summary of the results is provided in Table 2 . The calculated lanthanum and ytterbium concentrations in the melts were very similar, which implies that all three phases may have crystallized in equilibrium and that the REEs are not preferentially incorporated in the merrillite relative to apatite.

Table 2. Melt composition recalculated on the basis of a trace element concentration in apatite, merrillite and pyroxene.

\begin{tabular}{lllll}
\hline Mineral & Average La Content (ppm) & Kd & Source & Melt Composition (ppm) \\
\hline Apatite & 52 & 1.1 & {$[61]$} & 47 \\
Merrillite & 137 & 4.32 & GERM & 32 \\
Fe-Rich cpx & 0.048 & 0.001 & GERM & 48 \\
\hline Mineral & Average Yb Content (ppm) & Kd & Source & Melt Composition (ppm) \\
\hline Apatite & 39 & 2.3 & {$[61]$} & 17 \\
Merrillite & 73 & 8 & {$[61]$} & 9 \\
Fe-Rich cpx & 1.16 & 0.065 & GERM & 12 \\
\hline
\end{tabular}

$\mathrm{Cl}$-rich apatite, which seems to replace merrillite, shows large variations in $\mathrm{Cl}$ and $\mathrm{Cl} / \mathrm{OH}$ contents (Figure 4). Both might be related to crystallization stimulated by local saturation in volatile contents with variable $\mathrm{Cl}$ and $\mathrm{OH}$ proportions. Such crystallization cannot be related to fractional crystallization of a mafic melt and instead requires open system conditions [13,15]. In Figure 9, the Cl-rich apatite composition falls into the assimilation field, suggesting assimilation of crustal material or interaction with fluids. Hot fluids related to F-rich silicate liquids on Earth are $\mathrm{Cl}$-rich and $\mathrm{H}_{2} \mathrm{O}$-poor $[62,63]$. The same relationship occurs in the evolution of Martian magma [8]. In hot Cl-rich fluids that are equilibrated with the residual melt, $\mathrm{Cl}$ is more strongly partitioned into the melt (after $\mathrm{F}$ is exhausted), which involves the loss of water to the fluid phase $[8,15,64]$. In NWA 2975, the residual melt was degassed before $\mathrm{F}$ was depleted. The results of Ustunisik et al. [56,57] and Howarth et al. [39] suggest the loss of $\mathrm{Cl}$ to fluids. The late infiltration of $\mathrm{Cl}$-rich brine can result in the appearance of Cl-rich minerals or Cl-enriched apatite [10,39,40,64-66].

The geochemistry of $\mathrm{Cl}$-rich apatites indicates their likely occurrence as a result of interactions with fluids. However, are the fluids exsolved only from evolved mafic magma? The NWA $2975 \mathrm{Cl}$-apatite is enriched in REEs in comparison to F-apatite (Figure 5). Cl-rich fluids are commonly LREE-rich due to fluid/melt partitioning of LREEs in the presence of $\mathrm{Cl}$ under hydrothermal conditions [40,67-69]. 
The $\mathrm{Cl}$-apatite REE pattern should be expected to be enriched in LREEs. Very distinct enrichment is not observed. The location of $\mathrm{Cl}$-apatite in the assimilation field (Figure 9) and the REE pattern might point to an origin associated with exogenous fluids mixed with fluids exsolved from evolved magma.

Fluids are considered to be a factor stimulating the transformation of REE-bearing phosphates into other REE-rich phosphates in Martian rocks (e.g., [16]). Cl-rich apatite replacing merrillite due to post-crystallization metasomatism is reported by many authors [10,14,39]. Many results relate $\mathrm{Cl}$-apatite to the interaction of merrillite with $\mathrm{Cl}$-rich crustal fluids circulating in the Martian crust.

The huge variation in halogen concentrations in Martian phosphate observed by Bellucci et al. [70] indicates heterogeneous, varied sources of their origin. This diversity is confirmed by the difference in $8^{37} \mathrm{Cl}$. Bellucci et al. [70] suggest halogen cycling via brines, which have been recognized on Martian surface.

Additional indication of the fluid-rock interaction as the origin of the $\mathrm{Cl}$-rich pattern was provided by the Eu anomaly in studied apatites. In the apatite/fluid interaction process, the REE partitioning is different from that occurring during apatite crystallization from melt [13,71]. Eu is more compatibly incorporated from fluids than from melts. Consequently, the normalized REE patterns for apatite crystals originating from the interactions of fluids show a positive Eu anomaly, whereas those from melts show a negative Eu anomaly. Santos et al. [14] found apatites with positive Eu anomalies in phosphate clasts in NWA 7034; however, they related it to a source region process.

The Eu anomaly may denote a change in the oxygen fugacity during the crystallization process or may be derived from the order of the mineral fractionation [13,72]. It is difficult to relate the anomaly to oxygen fugacity because it was defined as changeable by He et al. [30] during NWA 2975 basalt crystallization. The investigated F-rich apatite from NWA 2975 demonstrates a negative Eu anomaly, which most likely resulted from prior plagioclase fractionation. In Figure 5, apatite close to merrillite shows a positive Eu anomaly. The positive Eu anomaly might be a result of fluid participation in their formation.

Some grains of $\mathrm{Cl}$-rich apatite occur without merrillite. Therefore, another question is whether they might appear due to volatile exchange between an F-rich apatite existing next to merrillite and a fluid. Previously, it was believed that apatite is more retentive of volatiles than silicate melts or glasses. It was shown that this mineral is able to preserve the magmatic volatile contents in volcanic rocks in which the glasses are largely degassed [33,73]. The alteration of volatile composition after apatite formation is difficult [74] and even the treatment of fluorapatite with supercritical $\mathrm{HCl}$ fluids is ineffective for promoting halogen exchange [75]. However, it was recently reported that successful ion exchange in $\mathrm{F}-\mathrm{OH}$ apatite crystalline solutions is possible in controlled laboratory conditions [76]. The study of diffusion coefficients in apatite [76] showed that variations in $\mathrm{P}, \mathrm{T}$ or fluid/melt chemistry may results in $\mathrm{F}-\mathrm{Cl}-\mathrm{OH}$ zoning, but that research included experiments only for relatively high temperatures from 800 to $1250{ }^{\circ} \mathrm{C}$ [77]. Furthermore, Higashi et al. [78] demonstrated that the activation energy for hydrogen diffusion is lower than that of $\mathrm{F}$ and $\mathrm{Cl}$, which makes the diffusion rate of $\mathrm{H}$ several orders of magnitude higher than that of the other elements. Fast diffusion could affect the hydrogen exchange (isotopic signature) but should not have a dominant influence on the behaviour of $\mathrm{F}$ and $\mathrm{Cl}$ in the structure. There is a significant variation in the $\mathrm{OH}$ content in $\mathrm{Cl}$-rich apatite, but none of the $\mathrm{Cl}$-rich crystals revealed any F-rich apatite domains.

Howarth et al. [26] documented apatites affected by shock melts. Apatite-melt interaction caused devolatization of some crystal parts and significant $\mathrm{Cl}$ enrichment in the adjacent regions. F-apatite from NWA 2975 exhibits shock effects. We have not found any evidence of devolatization of apatite; however, CL images show the marginal parts were affected by fluids. The rock is covered by a glassy fusion crust and contains partly recrystallized glass pockets, which can be inferred to be drops of residual melt. In many places, chlorapatite occurs in the form of well-developed crystals close to glassy pockets with poorly recrystallized silica. 
Chlorapatite from NWA 2975 seems to be resistant to shock or was formed after the shock event. An indication of its origin may be an experiment performed by Adcock et al. [79], which revealed that chlorapatite is resistant to shock. Thus, the first possibility is more likely.

\section{Implications}

Apatite from shergottite has been thought a reliable and valid source of information about water content in Martian magma and, consequently, also in the Martian mantle. Increasing amounts of data have appeared in recent years indicating that apatite crystallization may be related to many processes during magma crystallization, as well as to many processes defined as interaction with $\mathrm{Cl}$-rich fluids. After crystallization, the apatite composition may also be changed due to volatile exchange. The multiplicity of recognized pathways of apatite crystallization/transformation gives us insight into many environments and allows us to recognize their composition and processes in them. However, the origin of apatite needs to be identified in detail. It is likely that some Cl-apatites identified as magmatic are actually of secondary origin, occurring as a product of post-magmatic processes in an environment contaminated by fluids or melts.

A detailed study on apatites and merrillite from NWA 2975 shows the whole sequence of processes leading to phosphate formation/transformation in magmatic and post-magmatic environments. The research results indicated that the recognized volatiles budget of two generations of fluorapatite was highly related to its magmatic origin. Apatite crystals formed from an evolved magma during its final differentiation and degassing stage. In turn, chlorapatite replaced ferromerrillite-merrillite and is not related to the primordial, mantle-derived shergottite magma. The relationship between merrillite and apatite indicates that apatite is most likely a product of merrillite reaction with fluids. The geochemical and TEM study shows that, among the three types of apatite in the shergottite NWA 2975, only the fluorapatite ( $\mathrm{F}-\mathrm{Cl}-\mathrm{OH}$-rich) is a reliable source for assessing the degree of Martian mantle hydration. The occurrence of apatite with merrillite requires detailed recognition of their mutual relationship. Consequently, the automatic use of apatite to assess the water content of the magma source can lead to completely false assumptions if the origin of the apatite is not precisely defined.

Supplementary Materials: The following are available online at: http:/ /www.mdpi.com/2076-3263/7/4/99/s1. Table S1: Representative and mean compositions of fluorapatite and chlorapatite from the Martian shergottite NWA 2975; Table S2: Representative and mean compositions of ferromerrillite-merrillite solid solutions from the Martian shergottite NWA 2975; Table S3: Trace element (LA-ICP-MS) analyses of apatite and merrillite.

Acknowledgments: This work benefited much from constructive comments of two anonymous reviewers. We would like to acknowledge Richard $\mathrm{Li}$ for editorial support. The study was funded by NCN 2011/01/B/ST10/04541, COST action TD 1308 “Origins", and IGS PAS project "Regolith". We would like to thank Oona Appelt for collecting EPMA data and Ilona Schäpan for SEM-EDS work, Dieter Rhede for preliminary Cl-apatite analyses, and Anja Schreiber for preparation of foils for TEM study.

Author Contributions: Ewa Słaby conceived the research; Richard Wirth performed TEM analyses and analyzed the data; Ewa Słaby, Hans-Jürgen Förster and Alicja Giera analyzed the EMPA data; Ewa Słaby, Łukasz Birski and Izabela Moszumańska analyzed the LA-ICP-MS data; the discussion and implications have been prepared by all Authors; and Ewa Słaby, Richard Wirth, Hans-Jürgen Förster, Łukasz Birski and Alicja Wudarska wrote the paper.

Conflicts of Interest: The authors declare no conflict of interest.

\section{References}

1. Rubin, A.E. Mineralogy of meteorite groups. Meteorit. Planet. Sci. 1997, 32, 231-247. [CrossRef]

2. McSween, H.Y., Jr.; Treiman, A.H. Martian meteorites. In Planetary Materials; Papike, J.J., Ed.; Reviews in Mineralogy and Geochemistry; Mineralogical Society of America: Chantilly, VA, USA, 1998; Volume 36, pp. 601-654. ISBN 0-939950-46-4.

3. Piccoli, P.M.; Candela, P.A. Apatite in igneous systems. In Phosphates: Geochemical, Geobiological, and Materials Importance; Kohn, M.J., Rakovan, J., Hughes, J.M., Eds.; Reviews in Mineralogy and Geochemistry; Mineralogical Society of America: Washington, DC, USA, 2002; Volume 48, pp. 255-292, ISBN 0-939950-60-X. 
4. Hughes, J.M.; Jolliff, B.L.; Gunter, M.E. The atomic arrangement of merrillite from the Fra Mauro formation, Apollo 14 lunar mission: The first structure of merrillite from the Moon. Am. Mineral. 2006, 91, 1547-1552. [CrossRef]

5. Hughes, J.M.; Jolliff, B.L.; Rakovan, J. The crystal chemistry of whitlockite and merrillite and the dehydrogenation of whitlockite to merrillite. Am. Mineral. 2008, 93, 1300-1305. [CrossRef]

6. Jolliff, B.L.; Hughes, J.M.; Freeman, J.J.; Zeigler, R.A. Crystal chemistry of lunar merrillite and comparison to other meteoritic and planetary suites of whitlockite and merrillite. Am. Mineral. 2006, 91, 1583-1595. [CrossRef]

7. Patiño Douce, A.E.; Roden, M. Apatite as a probe of halogen and water fugacities in the terrestrial planets. Geochim. Cosmochim. Acta 2006, 70, 3173-3196. [CrossRef]

8. McCubbin, F.M.; Nekvasil, H. Maskelynite-hosted apatite in the Chassigny meteorite: Insight into late-stage magmatic volatile evolution in martian magmas. Am. Mineral. 2008, 93, 676-684. [CrossRef]

9. Patiño Douce, A.E.; Roden, M.; Chaumba, J.; Fleisher, C.; Yogodzinski, G. Compositional variability of terrestrial mantle apatites, thermodynamic modeling of apatite volatile contents, and the halogen and water budgets of planetary mantles. Chem. Geol. 2011, 288, 14-31. [CrossRef]

10. Shearer, C.K.; Burger, P.; Papike, J.; Sharp, Z.; McKeegan, K.D. Fluids on differentiated asteroids: Evidence for phosphates in differentiated meteorites GRA 06128 and GRA 06129. Meteorit. Planet. Sci. 2011, 46, 1345-1362. [CrossRef]

11. McCubbin, F.M.; Hauri, E.H.; Elardo, S.M.; Van der Kaaden, K.E.; Wang, J.; Shearer, C.K. Hydrous melting of the martian mantle produced both depleted and enriched shergottites. Geology 2012, 40, 683-686. [CrossRef]

12. McCubbin, F.M.; Shearer, C.K.; Burger, P.V.; Hauri, E.H.; Wang, J.; Elardo, S.M.; Papike, J.J. Volatile abundances of coexisting merrillite and apatite in the martian meteorite Shergotty: Implications for merrillite in hydrous magmas. Am. Mineral. 2014, 99, 1347-1354. [CrossRef]

13. Lesnov, F.P. Consistent pattern of rare earth elements distribution in accessory minerals from rocks of mafic-ultramafic complexes. Open Geosci. 2013, 5, 112-173. [CrossRef]

14. Santos, A.R.; Agee, C.B.; McCubbin, F.M.; Shearer, C.K.; Burger, P.V.; Sharp, Z.D.; Zimmer, M. Apatite and merrillite from martian meteorite NWA 7034. In LPI Contribution No. 1719, Proceedings of the 44th Lunar and Planetary Science Conference, The Woodlands, TX, USA, 18-22 March 2013; Lunar and Planetary Institute: Houston, TX, USA, 2013; Abstract number: 2601.

15. Boyce, J.W.; Tomlinson, S.M.; McCubbin, F.M.; Greenwood, J.P.; Treiman, A.H. The Lunar Apatite Paradox. Science 2014, 344, 400-402. [CrossRef] [PubMed]

16. Liu, Y.; Ma, C.; Beckett, J.R.; Chen, Y.; Guan, Y. Rare-earth-element minerals in martian breccia meteorites NWA 7034 and 7533: Implications for fluid-rock interaction in the martian crust. Earth Planet. Sci. Lett. 2016, 451, 251-262. [CrossRef]

17. Adcock, C.T.; Tschauner, O.; Hausrath, E.M.; Udry, A.; Luo, S.N.; Cai, Y.; Ren, M.; Lanzirotti, A.; Newville, M.; Kunz, M.; Lin, C. Shock-transformation of whitlockite to merrillite and the implications for meteoritic phosphate. Nat. Commun. 2017, 8, 14667. [CrossRef] [PubMed]

18. Balta, J.B.; McSween, H.Y., Jr. Water and the composition of Martian magmas. Geology 2013, 41, 1115-1118. [CrossRef]

19. Filiberto, J.; Gross, J.; McCubbin, F.M. Constraints on the water, chlorine, and fluorine content of the Martian mantle. Meteorit. Planet. Sci. 2016, 51, 2023-2035. [CrossRef]

20. Shearer, C.K.; Burger, P.V.; Papike, J.J.; McCubbin, F.M.; Bell, A.S. Crystal chemistry of merrillite from Martian meteorites: Mineralogical recorders of magmatic processes and planetary differentiation. Meteorit. Planet. Sci. 2015, 50, 649-673. [CrossRef]

21. McCubbin, F.M.; Boyce, J.W.; Srinivasan, P.; Santos, A.R.; Elardo, S.M.; Filiberto, J.; Steele, A.; Shearer, C.K. Heterogeneous distribution of $\mathrm{H}_{2} \mathrm{O}$ in the Martian interior: Implications for the abundance of $\mathrm{H}_{2} \mathrm{O}$ in depleted and enriched mantle sources. Meteorit. Planet. Sci. 2016, 51, 2036-2060. [CrossRef]

22. Xie, X.; Minitti, M.E.; Chen, M.; Wang, D.; Mao, H.; Shu, J.; Fei, Y. Natural high-pressure polymorph of merrillite in the shock vein of the Suizhou meteorite. Geochim. Cosmochim. Acta 2002, 66, 2439-2444. [CrossRef]

23. Xie, X.; Minitti, M.E.; Chen, M.; Mao, H.; Wang, D.; Shu, J.; Fei, Y. Tuite, $\gamma-\mathrm{Ca}_{3}\left(\mathrm{PO}_{4}\right)_{2}$ : A New mineral from Suizhou L6 chondrite. Eur. J. Mineral. 2003, 15, 1001-1005. [CrossRef] 
24. Xie, X.; Zhai, S.; Chen, M.; Yang, $\mathrm{H}$. Tuite, $\gamma-\mathrm{Ca}_{3}\left(\mathrm{PO}_{4}\right)_{2}$, formed by chlorapatite decomposition in a shock vein of the Suizhou L6 chondrite. Meteorit. Planet. Sci. 2013, 48, 1515-1523. [CrossRef]

25. Llorca, J.; Trigo-Rodríguez, J.M. Raman spectroscopy of merrillite in Villalbetode la Peña L6 ordinary chondrite. In LPI Contribution No. 1303, Proceedings of the 37th Lunar and Planetary Science Conference, League City, Texas, USA, 13-17 March 2006; Lunar and Planetary Institute: Houston, TX, USA, 2006; Abstract number: 1055.

26. Howarth, G.H.; Pernet-Fisher, J.F.; Bodnar, R.J.; Taylor, L.A. Evidence for the exsolution of Cl-rich fluids in martian magmas: Apatite petrogenesis in the enriched lherzolitic shergottite Northwest Africa 7755. Geochim. Cosmochim. Acta 2015, 166, 234-248. [CrossRef]

27. Jolliff, B.L.; Haskin, L.A.; Colson, R.O.; Wadhwa, M. Partitioning in REE-saturating minerals: Theory, experiment, and modeling of whitlockite, apatite, and evolution of lunar residual magmas. Geochim. Cosmochim. Acta 1993, 57, 4069-4094. [CrossRef]

28. Filiberto, J.; Treiman, A.H. Martian magmas contained abundant chlorine, but little water. Geology 2009, 37, 1087-1090. [CrossRef]

29. Wittke, J.H.; Bunch, T.E.; Irving, A.J.; Farmer, M.; Strope, J. Northwest Africa 2975: An evolved basaltic shergottite with vesicular glass pockets and trapped melt inclusions. In LPI Contribution No. 1303, Proceedings of the 37th Lunar and Planetary Science Conference, League City, TX, USA, 13-17 March 2006; Lunar and Planetary Institute: Houston, TX, USA, 2006; Abstract number: 1368.

30. He, Q.; Hsu, W.; Xiao, L.; Guan, Y. Petrography and geochemistry of the shergottite Northwest Africa 2975. In LPI Contribution No. 1608, Proceedings of the 42nd Lunar and Planetary Science Conference, The Woodlands, Texas, USA, 7-11 March 2011; Lunar and Planetary Institute: Houston, TX, USA, 2011; Abstract number: 1646.

31. Channon, M.B.; Boyce, J.W.; Stolper, E.M.; Eiler, J.M. Abundances of Cl, F, H, and S in apatites from martian meteorites. In LPI Contribution No. 1659, Proceedings of the 43rd Lunar and Planetary Science Conference, The Woodlands, Texas, USA, 19-23 March 2012; Lunar and Planetary Institute: Houston, TX, USA, 2012; Abstract number: 2845.

32. Channon, M.B.; Boyce, J.W.; Stolper, E.M.; Eiler, J.M. Abundances of Cl, F, H, and S in apatites from SNC meteorites. In Meteoritics \& Planetary Science, Proceedings of the 74th Annual Meeting of the Meteoritical Society, London, U.K. 8-12 August 2011; The Meteoritical Society: Chantilly, VA, USA, 2011; Volume 46, Abstract number: 5401.

33. Tartèse, R.; Anand, M.; McCubbin, F.M.; Elardo, S.M.; Shearer, C.K.; Franchi, I.A. Apatites in lunar KREEP basalts: The missing link to understand the H isotope systematics of the Moon. Geology 2014, 42, 363-366. [CrossRef]

34. McCubbin, F.M.; Jones, R.H. Extraterrestrial Apatite: Planetary Geochemistry to Astrobiology. Elements 2015, 11, 183-189. [CrossRef]

35. Mikouchi, T.; Miyamato, M.; McKay, G.A. Mineralogy of Antarctic basaltic shergottite Queen Alexandra Range 94201: Mineralogical similarities to Elephant Moraine A79001 (lithology B) Martian meteorite. Meteorit. Plant. Sci. 1998, 33, 181-189. [CrossRef]

36. Herd, C.D.K.; Treiman, A.H.; McKay, G.A.; Shearer, C.K. The behavior of Li and B during planetary basalt crystallization. Am. Mineral. 2004, 89, 832-840. [CrossRef]

37. Channon, M.B. Oxygen Isotopes and Volatiles in Martian Meteorites. Ph.D Thesis, California Institute of Technology, Pasadena, CA, USA, 2013.

38. Shearer, C.K.; Papike, J.J.; Burger, P.V.; Sutton, S.R.; McCubbin, F.M.; Newville, M. Direct determination of europium valence state by XANES in extraterrestrial merrillite: Implications for REE crystal chemistry and martian magmatism. Am. Mineral. 2011, 96, 1418-1421. [CrossRef]

39. Howarth, G.H.; Liu, Y.; Chen, Y.; Pernet-Fisher, J.N.; Taylor, L.A. Postcrystallization metasomatism in shergottites: Evidence from the paired meteorites LAR 06319 and LAR 12011. Meteorit. Planet. Sci. 2016, 51, 2061-2072. [CrossRef]

40. McCubbin, F.M.; Elardo, S.M.; Shearer, C.K.; Smirnov, A.; Hauri, E.H.; Draper, D.S. A petrogenetic model for the comagmatic origin of chassignites and nakhlites: Inferences from chlorine-rich minerals, petrology, and geochemistry. Meteorit. Planet. Sci. 2013, 48, 819-853. [CrossRef]

41. He, Q.; Xiao, L.; Balta, J.B.; Baziotis, I.P.; Hsu, W.; Guan, Y. Petrography and geochemistry of the enriched basaltic shergottite Northwest Africa 2975. Meteorit. Planet. Sci. 2015, 50, 2024-2044. [CrossRef] 
42. Słaby, E.; Koch-Müller, M.; Förster, H-J.; Wirth, R.; Rhede, D.; Schreiber, A.; Schade, U. Determination of volatile concentrations in fluorapatite of Martian shergottite NWA 2975 by combining synchrotron FTIR, Raman spectroscopy, EMPA, and TEM, and inferences on the volatile budget of the apatite host-magma. Meteorit. Planet. Sci. 2016, 51, 1-17. [CrossRef]

43. Lindsay, F.N.; Osmond, J.; Delaney, J.S.; Herzog, G.F.; Turrin, B.; Park, J.; Swisher, C.C. III Ar/Ar systematics of Martian meteorite NWA 2975. In LPI Contribution No. 1719, Proceedings of the 44th Lunar and Planetary Science Conference, The Woodlands, TX, USA, 18-22 March 2013; Lunar and Planetary Institute: Houston, TX, USA, 2013; Abstract number: 2911.

44. Müller, W.; Shelley, M.; Miller, P.; Broude, S. Initial performance metrics of a new custom-designed ArF excimer LA-ICPMS system coupled to a two-volume laserablation cell. J. Anal. At. Spectrom. 2009, 24, 209-214. [CrossRef]

45. Pearce, N.J.G.; Perkins, W.T.; Westgate, J.A.; Gorton, M.P.; Jackson, S.E.; Neal, C.R.; Chenery, P. A Compilation of New and Published Major and Trace Element Data for NIST SRM 610 and NIST SRM 612 Glass Reference Materials. Geostandard Newslett. 1997, 21, 115-144. [CrossRef]

46. Wirth, R. Focused Ion Beam (FIB): A novel technology for advanced application of micro- and nanoanalysis in geosciences and applied mineralogy. Eur. J. Mineral. 2004, 16, 863-876. [CrossRef]

47. Wirth, R. Focused Ion Beam (FIB) combined with SEM and TEM: Advanced analytical tools for studies of chemical composition, microstructure and crystal structure in geomaterials on a nanometre scale. Chem. Geol. 2009, 261, 217-229. [CrossRef]

48. Kayama, M.; Nishido, H.; Sekine, T.; Nakazato, T.; Gucsik, A.; Ninagawa, K. Shock barometer using cathodoluminescence of alkali feldspar. J. Geophys. Res. 2012, 117, 1-13. [CrossRef]

49. Irber, $\mathrm{W}$. The lanthanide tetrad effect and its correlation with $\mathrm{K} / \mathrm{Rb}, \mathrm{Eu} / \mathrm{Eu}^{*}, \mathrm{Sr} / \mathrm{Eu}, \mathrm{Y} / \mathrm{Ho}$ and $\mathrm{Zr} / \mathrm{Hf}$ of evolving peraluminous granite suits. Geochim. Cosmochim. Acta 1999, 63, 489-508. [CrossRef]

50. Greenwood, J.P.; Itoh, S.; Sakamoto, N.; Vicenzi, E.P.; Yurimoto, H. Hydrogen isotope evidence for loss of water from Mars through time. Geophys. Res. Lett. 2008, 35, L05203. [CrossRef]

51. Holland, H.D. Granites, solutions, and base metal deposits. Econ. Geol. 1972, 67, 281-301. [CrossRef]

52. Kilinc, I.A.; Burnham, C.W. Partitioning of chloride between a silicate melt and coexisting aqueous phase from 2 to 8 kbar. Econ. Geol. 1972, 67, 231-235. [CrossRef]

53. Candela, P.A. Toward a thermodynamic model for the halogens in magmatic systems-an application to melt vapor apatite equilibria. Chem. Geol. 1986, 57, 289-301. [CrossRef]

54. Carroll, M.R.; Webster, J.D. Solubilities of sulfur, noble gases, nitrogen, chlorine, and fluorine in magmas. Rev. Mineral. Geochem. 1994, 30, 231-279.

55. Webster, J.D.; Kinzler, R.J.; Mathez, E.A. Chloride and water solubility in basalt and andesite melts and implications for magmatic degassing. Geochim. Cosmochim. Acta 1999, 63, 729-738. [CrossRef]

56. Ustunisik, G.; Nekvasil, H.; Lindsley, D. Differential degassing of $\mathrm{H}_{2} \mathrm{O}, \mathrm{Cl}, \mathrm{F}$, and S: Potential effects on lunar apatite. Am. Mineral. 2011, 96, 1650-1653. [CrossRef]

57. Ustunisik, G.; Nekvasil, H.; Lindsley, D.H.; McCubbin, F.M. Degassing pathways of Cl-, F-, H-, and S-bearing magms near lunar surface: Implications for the composition and $\mathrm{Cl}$ isotopic values of lunar apatite. Am. Mineral. 2015, 100, 1717-1727. [CrossRef]

58. McCubbin, F.M.; Vander Kaaden, K.E.; Whitson, E.S.; Bell, A.S.; Shearer, C.K., Jr. Partitioning of F and Cl between apatite and a synthetic shergottite liquid (QUE 94201) at 1 and 4 GPa from 950 to $1450^{\circ} \mathrm{C}$. In LPI Contribution No. 1719, Proceedings of the 44th Lunar and Planetary Science Conference, The Woodlands, TX, USA, 18-22 March 2013; Lunar and Planetary Institute: Houston, TX, USA, 2013; Abstract number: 2748.

59. Vander Kaaden, K.E.; McCubbin, F.M.; Whitson, E.S.; Hauri, E.H.; Wang, J. Partitioning of F, Cl, and $\mathrm{H} 2 \mathrm{O}$ between apatite and a synthetic shergottite liquid (QUE 94201) at $1.0 \mathrm{GPa}$ and $990-1000{ }^{\circ} \mathrm{C}$. In LPI Contribution No. 1659, Proceedings of the 43rd Lunar and Planetary Science Conference, The Woodlands, TX, USA, 19-23 March 2012; Lunar and Planetary Institute: Houston, TX, USA, 2012; Abstract number: 1247.

60. Ferdous, J.; Brandon, A.D.; Peslier, A.H.; Pirotte, Z. Evaluating crustal contributions to enriched shergottites from the petrology, trace elements, and $\mathrm{Rb}-\mathrm{Sr}$ and $\mathrm{Sm}-\mathrm{Nd}$ isotope systematic of Northwest Africa 856. Geochim. Cosmochim. Acta 2017, 211, 280-306. [CrossRef]

61. Murrell, M.T.; Brandriss, M.; Woolum, D.S.; Burnett, D.S. Pu-REE-Y partitioning between apatite and whitlockite. In LPI Contribution No. 1581, Proceedings of the 15th Lunar and Planetary Science Conference, 
Houston, TX, USA, 12-16 March 1984; Lunar and Planetary Institute: Houston, TX, USA, 1984; pp. 579-580, Abstract number: 1294 .

62. Webster, J.D.; Tappen, C.M.; Mandewille, C.W. Partitioning behavior of chlorine and fluorine in the system apatite-melt-fluid. II: Felsic silicate system at $200 \mathrm{MPa}$. Geochim. Cosmochim. Acta 2009, 73, 559-581. [CrossRef]

63. Webster, J.D.; Rebbert, C.R. Experimental investigation of $\mathrm{H}_{2} \mathrm{O}$ and $\mathrm{Cl}$ - solubilities in F-enriched silicate liquids; implications for volatile saturation of topaz rhyolite magmas. Contrib. Mineral. Petrol. 1998, 132, 198-207. [CrossRef]

64. Mathez, E.A.; Webster, J.D. Partitioning behavior of chlorine and fluorine in the system apatite-silicate melt-fluid. Geochim. Cosmochim. Acta 2005, 69, 1275-1286. [CrossRef]

65. Boudreau, A.E.; McCallum, I.S. Investigations of the Stillwater Complex: Part V. Apatites as indicators of evolving fluid composition. Contrib. Mineral. Petrol. 1989, 102, 138-153. [CrossRef]

66. Boudreau, A.E.; McCallum, I.S. Infiltration metasomatism in layered intrusions-An example from the Stillwater Complex, Montana. J. Volcanol. Geotherm. Res. 1992, 52, 171-183. [CrossRef]

67. Lieftink, D.J.; Nijland, T.G.; Maijer, C. The behavior of rare-earth elements in high-temperature Cl-bearing aqueous fluids-Resaults from the Odegarden-Verk natural laboratory. Can. Mineral. 1994, 32, 149-158.

68. Stadler, R.; Foley, S.F.; Brey, G.P.; Horn, I. Minieral aqueous fluid partitioning of trace elements at $900-1200{ }^{\circ} \mathrm{C}$ and 3.0-5.7 GPa: New experimental data for garnet, clinopyroxene, and rutile, and implications for mantle metasomatism. Geochim. Cosmochim. Acta 1998, 62, 1781-1801. [CrossRef]

69. Mayanovic, R.A.; Anderson, A.J.; Basset, W.A.; Chou, I.M. The structure and stability of aqueous rare-earth elements in hydrothermal fluids: New results on neodymium(III) aqua and chloroaqua complexes in aqueous solutions to 500 degrees C and $520 \mathrm{MPa}$. Chem. Geol. 2009, 259, 30-38. [CrossRef]

70. Bellucci, J.J.; Whitehouse, M.J.; John, T.; Nemchin, A.A.; Snape, J.F.; Bland, P.A.; Benedix, G.K. Halogen and $\mathrm{Cl}$ isotopic systematics in Martian phosphates: Implications for the $\mathrm{Cl}$ cycle and surface halogen reservoirs on Mars. Earth and Planet. Sci. Lett. 2017, 458, 192-202. [CrossRef]

71. Ayers, J.C.; Watson, E.B. Apatite/fluid partitioning of rare earth elements and strontium: Experimental results at $1.0 \mathrm{GPa}$ and $1000{ }^{\circ} \mathrm{C}$ and application to models of fluid/rock interaction. Chem. Geol. 1993, 110, 299-314. [CrossRef]

72. Chu, M.-F.; Wand, K.-L.; Griffin, W.L.; Chung, S.-L.; O’Reilly, S.Y.; Pearson, N.J.; Iizuka, Y. Apatite composition: Tracing petrogenetic processes in Transhimalayan granitoids. J. Petrol. 2009, 50, 1829-1855. [CrossRef]

73. Boyce, J.W.; Hervig, R.L. Magmatic degassing histories from apatite volatile stratigraphy. Geology 2008, 36, 63-66. [CrossRef]

74. Hovis, G.L.; Harlov, D. Solution calorimetric investigation of fluor-chlorapatite crystalline solutions. Am. Mineral. 2010, 95, 946-952. [CrossRef]

75. Harlov, D.E.; Wirth, R.; Förster, H.-J. An experimental study of dissolution reprecipitation in fluorapatite: Fluid infiltration and the formation of monazite. Contrib. Mineral. Petrol. 2005, 150, 268-286. [CrossRef]

76. Hovis, G.L.; McCubbin, F.M.; Nekvasil, H.; Ustunisik, G.; Woerner, W.R.; Lindsley, D.H. A novel Technique for fluorapatite synthesis and the thermodynamic mixing behavior of $\mathrm{F}-\mathrm{OH}$ apatite crystalline solutions. Am. Mineral. 2014, 99, 890-897. [CrossRef]

77. Brenan, J. Kinetics of fluorine, chlorine and hydroxyl exchange in fluorapatite. Chem. Geol. 1993, 110, $195-210$. [CrossRef]

78. Higashi, Y.; Itoh, S.; Hashiguchi, M.; Sakata, S.; Hirata, T.; Watanabe, K.; Sakaguchi, I. Hydrogen diffusion in the apatite-water system: Fluorapatite parallel to the c-axis. Geochem. J. 2017, 51, 115-122. [CrossRef]

79. Adcock, C.T.; Tschauner, O.; Hausrath, E.M. An investigation of shock effects on Mars-relevant phosphate minerals: Shock-transformation of chlorapatite. In LPI Contribution No. 1903, Proceedings of the 47th Lunar and Planetary Science Conference, The Woodlands, TX, USA, 21-25 March 2016; Lunar and Planetary Institute: Houston, TX, USA, 2016; Abstract number: 1577.

(C) 2017 by the authors. Licensee MDPI, Basel, Switzerland. This article is an open access article distributed under the terms and conditions of the Creative Commons Attribution (CC BY) license (http:/ / creativecommons.org/licenses/by/4.0/). 